\title{
Unregulated aquaculture and invasive alien species: a case study of the African Catfish Clarias gariepinus in Vembanad Lake (Ramsar Wetland), Kerala, India
}

\author{
K. Krishnakumar ${ }^{1}$, Anvar Ali ${ }^{2}$, Benno Pereira ${ }^{3}$ \& Rajeev Raghavan ${ }^{4}$ \\ ${ }^{1}$ Community Environment Resource Center, Ashoka Trust for Research in Ecology and Environment (ATREE), Alleppey, Kerala, \\ India \\ ${ }^{2,3,4}$ Conservation Research Group (CRG), St. Albert's College, Kochi, Kerala, India \\ ${ }^{4}$ Durrell Institute of Conservation and Ecology, University of Kent, Canterbury, UK \\ Email: ${ }^{1}$ krishnakumar@atree.org, ${ }^{2}$ anvaraliif@gmail.com, ${ }^{3}$ bennopereira@gmail.com, ${ }^{4}$ rajeevraq@hotmail.com (corresponding \\ author)
}

Date of publication (online): 26 May 2011 Date of publication (print): 26 May 2011 ISSN 0974-7907 (online) | 0974-7893 (print)

Editor: Neelesh Dahanukar

\section{Manuscript details:}

Ms \# 02378

Received 30 December 2009

Final received 05 April 2011

Finally accepted 20 April 2011

Citation: Krishnakumar, K., A. Ali, B. Pereira \& R. Raghavan (2011). Unregulated aquaculture and invasive alien species: a case study of the African Catfish Clarias gariepinus in Vembanad Lake (Ramsar Wetland), Kerala, India. Journa of Threatened Taxa 3(5): 1737-1744.

Copyright: (c) K. Krishnakumar, Anvar Ali, Benno Pereira \& Rajeev Raghavan 2011. Creative Commons Attribution 3.0 Unported License. JoTT allows unrestricted use of this article in any medium for non-profit purposes, reproduction and distribution by providing adequate credit to the authors and the source of publication.

Author Details and Author Contribution: see end of this article

Acknowledgements: The authors thank the local fishers in Vembanad Lake for their help and assistance during the sampling. The first author thanks Priyadarsanan Dharmarajan (Fellow), Latha Bhaskar (Project Coordinator), Seena Narayanan (Research Associate), Aneesh A (Research Associate) at the Ashoka Trust for Research in Ecology and the Environment (ATREE), Bangaluru, India for their support. Two anonymous reviewers greatly improved the manuscript.
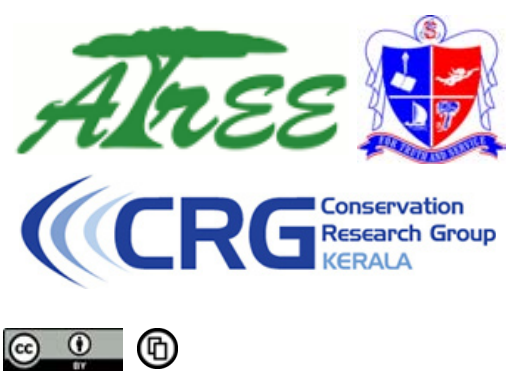

OPEN ACCESS | FREE DOWNLOAD
Abstract: Indiscriminate and illegal farming of the African Catfish Clarias gariepinus, in central Kerala has now resulted in the escape and spread of the species into Vembanad Lake, a large brackish water wetland and inland fish diversity hotspot. We collected 17 individuals of $C$. gariepinus ranging in size from 200 to $750 \mathrm{~mm}$ from different locations in the southern sector of the lake during a field survey conducted in 2007 . Samples comprised of mature specimens of both sexes indicating their reproductive potential in the study area. The possible impacts of spread of C. gariepinus into natural water bodies of Kerala, especially the Vembanad Lake, and options for their management are discussed.

Keywords: Aquaculture, Clarias gariepinus, exotic fish, introduction, illegal farming, invasive alien species, Vembanad Lake

\section{INTRODUCTION}

Aquaculture has been a major cause for introduction of exotic fish and shellfish worldwide (Naylor et al. 2001). Around 50 species of finfish that are alien to one nation or the other are being cultured in Asia (de Silva et al. 2006). These include species that are farmed in accordance with national laws and regulations as well as those that are illegally introduced and cultured. India, the second largest aquaculture producer in the world (FAO 2008-2009), has a thriving industry focusing on various cyprinids, freshwater prawn and marine shrimp. Around $40 \%$ of the national production is also contributed by various alien cyprinids, notably the common carp and different species of Chinese carps (de Silva et al. 2006). However, unregulated introduction and illegal farming of several new exotic species has been documented in the recent past (Raghavan \& Prasad 2006; Singh \& Lakra 2006). Several of these species are listed as potential pests, capable of negatively impacting the native aquatic biodiversity.

One such species is the African Catfish Clarias gariepinus, which is now widely farmed in many regions of Africa, Europe and Asia. Clarias gariepinus was brought to India from neighbouring Bangladesh (Thakur 1998) and cultured initially in the two northeastern states of West Bengal and Assam and the southern state of Andhra Pradesh, together with the Indian Major Carp (Baruah et al. 1999). Serious losses to the carp in such mixed culture ponds led farmers to switch over to monoculture of this predatory catfish (Baruah et al. 1999). The first consignment of catfish 
fry from Bangladesh via Andhra Pradesh reached the southern Indian state of Kerala in 1993 or early 1994 (Middendorp 1998), and since then it has been cultured in many parts of the state. One important area for African Catfish farming in Kerala has been in the vicinity of the Vembanad Lake in central Kerala - a region having a long history of fisheries-related activities, including inland capture fisheries and aquaculture.

Local fishers have reported stray catches of $C$. gariepinus from the many waterways that lie adjacent to the Vembanad Lake since the last decade (Gopi 2000). However, in recent years, increasing catches of $C$. gariepinus have been made from the main water body of the lake (K. Krishnakumar pers. obs.). Therefore our prime objective was to determine whether $C$. gariepinus has established a feral population in the Vembanad Lake, and if so what the repercussions could be for native ichthyofauna.

\section{METHODS}

Study area: The Vembanad - Kol wetland system $\left(09^{\circ} 00^{\prime}-10^{\circ} 40^{\prime} \mathrm{N} \& 76^{\circ} 00^{\prime}-77^{\circ} 30^{\prime} \mathrm{E}\right)$ and its 10 associated drainage basins are situated in the humid tropical region on the south west coast of the Indian peninsula. They are characterized by a continuous chain of lagoons or backwaters, 96km long, one of the largest estuarine systems in Kerala (WWF 2006). The wetland system covers an area of $1512 \mathrm{~km}^{2}$ and has been designated as a Ramsar Site. The lake is renowned for its live clam resources and subfossil deposits, as a habitat for the threatened Spot-billed Pelican Pelicanus philippensis, large bird population especially water fowls, besides a high species diversity of finfish and shellfish (WWF 2002). One-hundred -and-fifty species of fish belonging to 100 genera and 56 families are known to occur in Vembanad Lake (Kurup \& Samuel 1985).

Sampling and analyses: Detailed sampling was carried out during January to July 2007 at three sites located in the southern sector of Vembanad Lake (Fig. 1): Kaithapuzha Kayal, AC Canal and Punnamada Lake (Image 1). The sites were chosen based on the reports of local fishers on the netting of $C$. gariepinus in these regions. Experimental fishing was carried out at dawn (0500-0900 hr) and also during the night

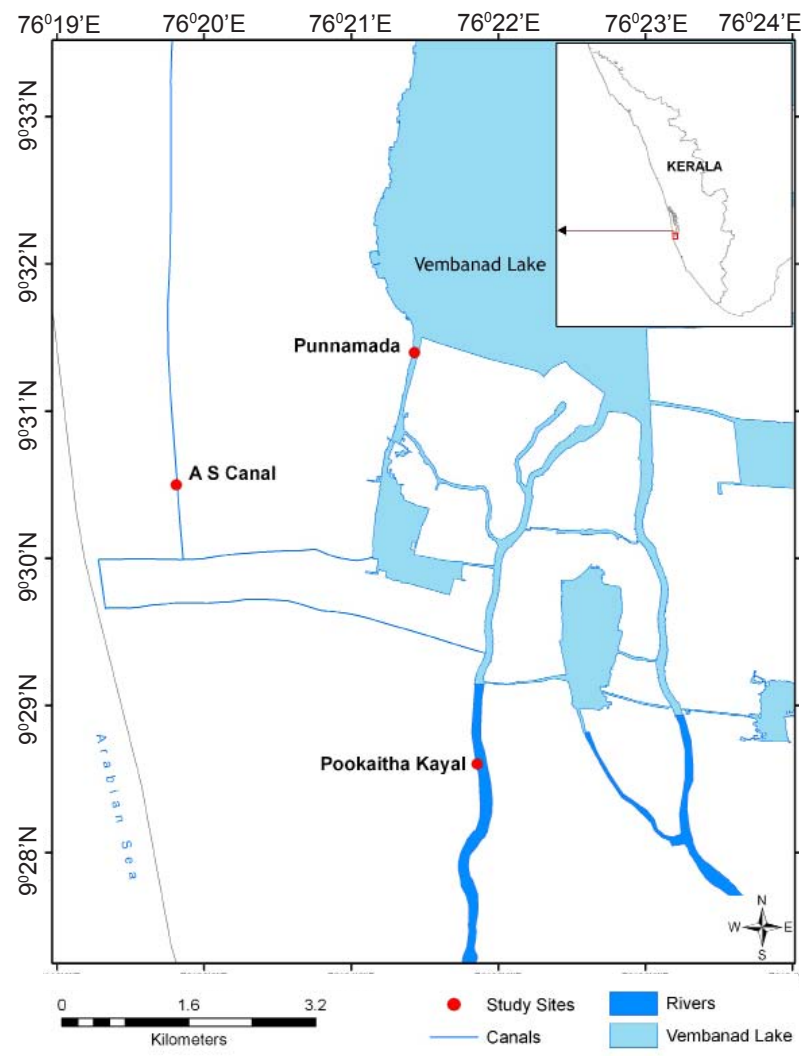

Figure 1. Map of Vembanad Lake showing sampling sites

(1830-0000 hr). A variety of gear including gill net, cast net, hook and line, and scoop net was used to avoid any sampling bias. In order to determine the relative robustness or degree of well-being of this exotic fish caught from Vembanad Lake, the coefficient of condition was calculated using the formula $\mathrm{K}=$ 100000L/W33 (Williams 2000).

\section{RESULTS}

We collected 17 individuals of $C$. gariepinus (Image 2) in the length group of 200 to $750 \mathrm{~mm}$ (total length) from the different sampling sites (Table 1). Fourteen individuals $(82 \%)$ collected from the lake had a coefficient of condition $(K)$ greater than one $(K$ $>1$ ) indicating that the species is performing well in this new habitat and that it could turn invasive in near future, because it will increase in numbers and start dominating the fish populations. Catches comprised of both sexes although the ratio was skewed in favour of females. Three individuals were identified as mature ( 2 males and 1 female) based on the development of 

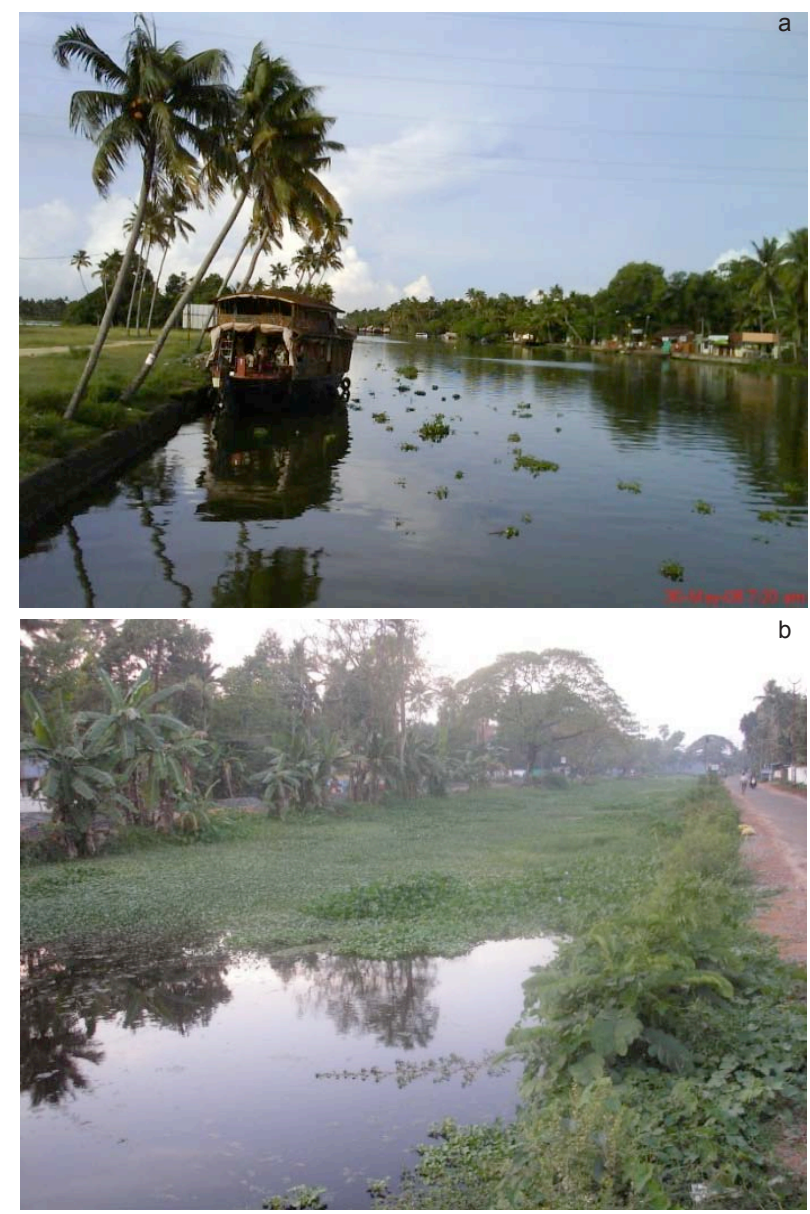

\begin{tabular}{|c|c|c|c|c|}
\hline $\begin{array}{l}\text { Total } \\
\text { Length } \\
(\mathrm{mm})\end{array}$ & $\begin{array}{l}\text { Body } \\
\text { Weight } \\
\text { (g) }\end{array}$ & Sex & Maturity & $\begin{array}{l}\text { Coefficient } \\
\text { of } \\
\text { conditioning } \\
\text { (K) }\end{array}$ \\
\hline 200 & 150 & Male & Immature & 0.5333 \\
\hline 250 & 200 & Male & Immature & 0.7813 \\
\hline 260 & 200 & Male & Immature & 0.8788 \\
\hline 280 & 225 & Male & Immature & 0.9756 \\
\hline 294 & 210 & Male & Immature & 1.2101 \\
\hline 300 & 225 & Male & Immature & 1.2000 \\
\hline 320 & 225 & Male & Immature & 1.4564 \\
\hline 350 & 250 & Male & Immature & 1.7150 \\
\hline 400 & 475 & Female & Immature & 1.3474 \\
\hline 402 & 530 & Female & Immature & 1.2258 \\
\hline 405 & 520 & Male & Immature & 1.2775 \\
\hline 480 & 650 & Male & Immature & 1.7014 \\
\hline 500 & 600 & Female & Immature & 2.0833 \\
\hline 593 & 750 & Female & Immature & 2.7804 \\
\hline 600 & 750 & Male & Immature & 2.8800 \\
\hline 650 & 1400 & Male & Mature & 1.9617 \\
\hline 700 & 1800 & Male & Mature & 1.9056 \\
\hline 750 & 2500 & Female & Mature & 1.6875 \\
\hline
\end{tabular}

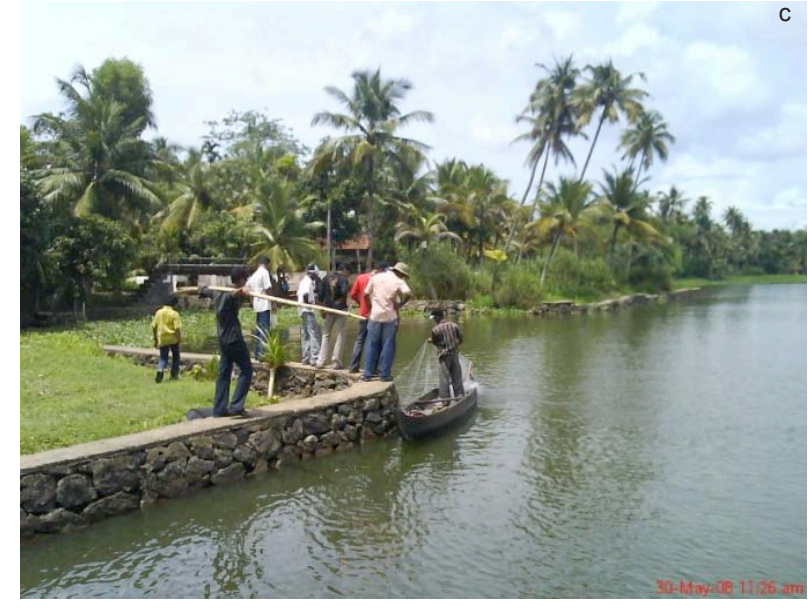

Image 1. Sampling sites. (a) S1 - Punnamada Kayal; (b) S2 A S Canal; (c) S3 - Pookaitha Kayal

testis and ovary which was observed after dissecting the specimens. All catches of $C$. gariepinus during our study were made from a hook and line baited with flesh and intestine of sardine. Ten individuals were caught during the early hours of the morning (0500$0700 \mathrm{hr}$ ) and seven during the night $(2100-2300 \mathrm{hr})$. Although a wide variety of fishing gears were used,
Table 1. Biological data of $C$. gariepinus individuals caught from Lake Vembanad.
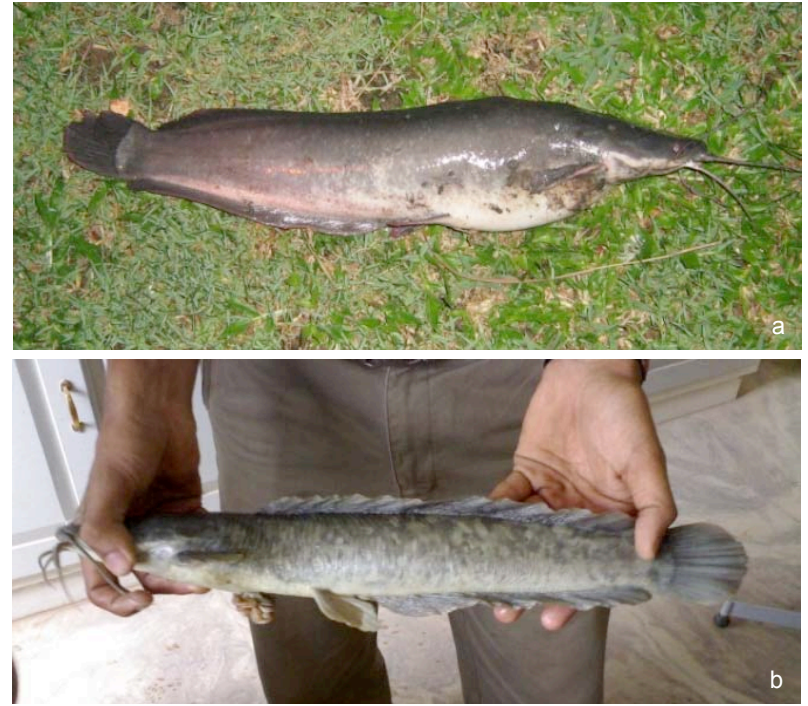

Image 2. Clarias gariepinus (a) Farm raised and (b) wild caught

we could collect $C$. garipeinus using only a hook and line. 


\section{DISCUSSION}

Kurup et al. (2004) reported the occurrence of C. gariepinus in farms of Kuttanad located along the Vembanad Lake in central Kerala. These farms could be the major source of $C$. gariepinus escapees into the Lake. The African Catfish has a tendency to leave the water at night using its strong pectoral fins and spines in search of land-based food (Burgess 1989) and also move into the breeding areas through very shallow pathway-movements which may be responsible for the fish being widely distributed in the Lake. The most obvious factor that could be attributed to the escape of pond reared individuals into the Lake is the physiographic nature of the region. Kuttanad is one of the highest flood prone areas in Kerala and most of the region is under flood waters of Vembanad Lake and its confluent rivers during the monsoon. Most farms in Kuttanad are traditional ones with little or no infrastructure (Image 3). Ponds are generally shallow and located in low lying areas adjoining the lake. Monsoon rains and associated flooding cause bunds and associated traditional sluice structures in the ponds to break frequently thereby facilitating the escape of the pond fish into the main water body of the lake. Such escapes are a common yearly occurrence in flood plains of the Chao Phraya River basin in central Thailand (Na-Nakorn 1999; Seenanan et al. 2004) where a thriving aquaculture activity of catfish takes place. Another important, but often overlooked reason for introduction of C. gariepinus in Vembanad Lake and its confluent waterways is the flourishing live fish trade. Several hundred large and small fish markets and landing centers are located along the banks of the Vembanad Lake where C. gariepinus and other native catfish are sold live. As with aquaculture farms in the region, landing centres and markets are mostly traditional with little or no infrastructure to support live fish trade. An added worry is the lack of knowledge on handling practices for live fish by the traders. Such markets and landing centres are hence a potential source from where $C$. gariepinus could escape into the lake.

Although aquaculture of C. gariepinus is banned in India vide the 9 October 1997 meeting of the National Committee for the introduction (screening/observing) of species (aquatic forms) (Gopi \& Radhakrishnan 2002), aquaculturists have taken little consideration for such bans and continue rearing this catfish. It is widely believed that the popularity for African catfish aquaculture is due to the simplicity in their rearing (Singh \& Lakra 2006). The low operational costs and high profits derived from African catfish farming have led to intensification of production. The most common strategy used to augment production is to increase the rearing density. Some farmers maintain very high stocking densities, higher than the carrying capacity of the ponds thereby aiding in escapes (Pascal et al. 2009).

The little or no management measures taken by farmers especially in preventing such escape of pond reared individuals has now resulted in the species being distributed in many natural water bodies of the country. C. gariepinus is now being increasingly caught from many rivers including Ganga, Yamuna, Sutlej and Godavari (Mishra et al. 2000; Sugunan 2002). An
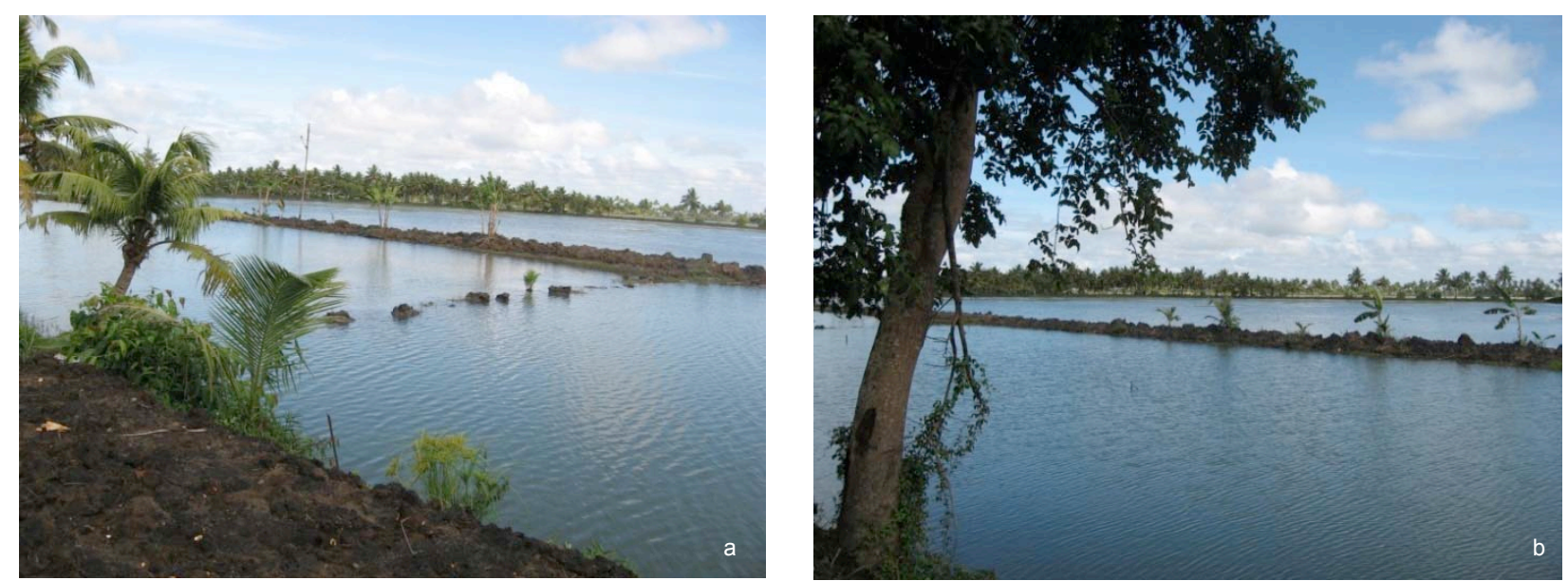

Image 3. Farms culturing Clarias gariepinus in the vicinity of Vembanad Lake 
unconfirmed report (Basheer 2003) mentions that the fish is now commonly caught by fisherman in Periyar River, Kerala, which incidentally is one of the confluent rivers of the Vembanad-Kole wetland. Gopi \& Radhakrishnan (2002) reported on the negative impacts of the introduction and culture of $C$. gariepinus on the native fish fauna of Manalur in Kerala. They observed that African Catfish escaped from rearing ponds in the area and got established in the larger community/ village ponds subsequently wiping out the indigenous species like snakeheads (Channa sp.). Apprehensions have been raised by local communities on the possible impacts to native fishes of the Kole-wetlands that lie adjacent to ponds stocked with $C$. gariepinus in the case of such escapes (Gopi \& Radhakrishnan 2002). African Catfish has also been observed from Periyar Lake in Kerala (Periyar Foundation 2006; Sudhi 2009), a hotspot harbouring many strictly endemic and Endangered native species (Lepidopygopsis typus, Nemacheilus menoni, Crossocheilus periyarensis, Hypselobarbus periyarensis, Garra periyarensis, Nemacheilus periyarensis). Vembanad Lake and its associated wetlands could provide the perfect habitat setting for $C$. gariepinus to invade and colonize as they are similar to the natural habitats of this species in Africa - calm lakes, rivers and swamps in areas that flood on a seasonal basis. C. gariepinus is a slowmoving, omnivorous predatory fish, which feeds on a variety of food items from microscopic zooplankton, to fish half its length, or $10 \%$ of its own body weight (de Graff \& Jansen 1996). They are also known to occasionally prey on reptiles, amphibians and birds (de Moor \& Bruton 1988). Vembanad Lake is an exceptionally rich wetland harbouring many species of aquatic organisms as well as amphibious reptiles and birds which could be potential prey for the catfish.

Another important aspect of predation by $C$. gariepinus is their ability to switch feeding from one type of prey to another (de Graff \& Jansen 1996). This could indicate a grave threat to all organisms that fall under the prey spectrum of $C$. gariepinus in case of a proliferation of population of this exotic catfish in Vembanad Lake. The presence of $C$. gariepinus in Vembanad Lake is especially a threat to highly prized native cichlids like Etroplus suratensis and Etroplus maculatus which resembles African cichlids that are common prey of $C$. gariepinus in its native ranges in Africa (Winemiller \& Kelso-Winemiller
1996). Vembanad Lake is also home to many species of freshwater and estuarine catfishes including Wallago attu, Mystus vittatus, Ompok bimaculatus and Heteropneustes fossilis that share similar trophic niche with $C$. gariepinus. As with the African Catfish, most native catfish are also carni-omnivores thereby indicating the possibility of increased competition for food resources. In addition, several omnivorous catfishes of Vembanad are listed as threatened due to their low abundance and declining populations (Molur \& Walker 1998). Such vulnerable species are particularly at risk due to the possible invasion of the ecosystem by a predator in the class of $C$. gariepinus. Introduction and subsequent colonization of $C$. gariepinus in new environments have led to decline and extermination of local species. Depletion of 56 species of native fish in Bangladesh has been linked to the introduction of $C$. gariepinus (Barua et al. 2000). Similarly, hybrid Clarias (C. gariepinus $\mathrm{x}$ C. macrocephalus) is known to have contributed to the decline of native $C$. batrachus in the Mekong Delta (Welcomme \& Vidthayanon 2003).

Our collections included at least three mature specimens (one female and two male) suggesting that the resident population has reproductive potential. Literature indicates that $C$. gariepinus can be sexually active from the first year of its life (Yalcin et al. 2001). Since the physiography and eco-biology of the Vembanad Lake including a seasonal monsoon is highly conducive to the natural breeding of $C$. gariepinus, it would not be long before the species breeds establishing a self sustaining population and subsequently colonizing the ecosystem. Apart from bio-ecological impacts, the invasion of African catfish in natural waters can also have long lasting genetic implications $C$. gariepinus was introduced into Thailand for hybridizing with the indigenous C. macrocephalus. The hybrid is now cultured extensively and is preferred by local farmers, because of its considerably higher growth rate than that of the indigenous species and desirable flesh quality (NaNakorn 1999). However, Senanan et al. (2004) and Na-Kakorn et al. (2004) observed the introgression of African Catfish genes into the native walking catfish C. macrocephalus in four wild and two broodstock populations in central Thailand. Native gene pools of C. macrocephalus was suggested to have been diluted and threatened, and if in the absence of appropriate 
management strategies the indigenous walking catfish could be potentially threatened as a result of massive backcrossing with hybrid catfish (Na-Nakorn et al. 2004). Similar problems have occurred in Bangladesh through the use of hybrid C. batrachus x C. gariepinus for aquaculture (Rahman et al. 1995). C. gariepinus in India has been suggested to be a mix of different stocks belonging to different genetic lineages (Lal et al. 2003).

We positively believe that $C$. gariepinus has established a feral population in Vembanad Lake and its associated wetlands. One reason for the nonappearance of this species in local fisherman's catches is due to the fact that $C$. gariepinus is known to seldom entangle in a gill net - which incidentally is the single most important gear used by local fishers in the region. Local fishers and aquaculturists having years of experience with inland catfishes have opined that African catfish have a tendency to break the gill nets which are laid overnight and so are conspicuously absent in gill net catches. The extent of spread of C. gariepinus in various natural water bodies of Kerala especially those that are located near areas where farming of this species takes place require comprehensive investigations. Vembanad Lake is an area that needs a more detailed focus as many small and large farms and live fish markets where $C$. gariepinus are handled occur in the vicinity of the lake as well as its confluent rivers. Determining the biological, demographical and genetic impacts of the presence and possible colonization of this predatory species on native fish fauna is an immediate research priority. It would also be worthwhile to conduct studies to determine the best techniques for capture and control of this predator.

The opportunistic strategy and ability to establish large and persistent populations makes $C$. gariepinus a threat to native fishes and livelihoods of inland fishers. Thus there is an immediate need for all stakeholders involved to discuss and deliberate the potential impacts of this problem and chalk out efficient strategies to combat them. Effectual control of alien species can only be undertaken through understanding the pathways of introduction and dispersal. In the case of Vembanad Lake, it is known that aquaculture ponds as well as live fish trade in the region are the two major sources of escapes. These pathways can therefore be regulated to an extent if the authority's commitment to protecting native biodiversity is enhanced and the inability or unwillingness to enforce laws that exist is looked into. Fugitive fish - those that escape from aquaculture facilities (Naylor et al. 2005) are a major cause for worry in salmon aquaculture. However, solutions including use of sterile animals and triploids (Benfey 2001; Sadler et al. 2001) are being tried to mitigate impacts due to the emerging issue of aquaculture escapees.

Effective management requires the availability of relevant background information. It is true that the ability to understand the problem of exotic species invasion in Kerala's inland waters has been extremely limited. Very little information is available on the occurrence and possible impacts of exotic species in the region (Raghavan et al. 2008). A healthy synergy is generally absent between scientists and policy makers in Kerala. A common caveat that has been put forth by policy makers from developing management plans and enforcing regulations is the lack of information on the occurrence and possible impacts of exotic fishes in Kerala. We expect that our present effort could be a start to more studies in the future that could bring insights into the emerging issue and compel the authorities to act in a rational manner.

\section{REFERENCES}

Barua, S.P., M.M. Khan \& M. Ameen (2000). The status of Alien Invasive Species in Bangladesh and their Impacts in the Ecosystem. IUCN Bangladesh, 7pp

Baruah, U.K., A.K. Bhagowati \& U.C. Goswami (1999). Culture of hybrid Magur (Clarias gariepinus X Clarias macrocephalus) in Assam. Indian Journal of Fisheries 46: 265-272.

Basheer, V.S. (2003). Badman's tropical fish - don't release that fish. http://badmanstropicalfish.com/dont_release comment.html; Accessed online on 18 March 2008

Benfey, T.J. (2001). Use of sterile triploid Atlantic Salmon (Salmo salar L) for aquaculture in New Brunswick, Canada. ICES Journal of Marine Sciences 58: 525-529.

Burgess, W.E. (1989). An atlas of freshwater and marine catfishes - A preliminary survey of the Siluriformes. T.F.H. Publications, Inc., Neptune City, New Jersey (USA), $784 \mathrm{pp}$.

de Graff, G. \& H. Jensen (1996). Artificial Reproduction and Pond Rearing of the African Catfish Clarias Gariepinus in Sub-Saharan Africa - A Handbook. FAO Fisheries Technical Paper 362, FAO Rome, Italy

de Moor, I.J. \& M.N. Bruton (1988). Atlas of alien and 
translocated indigenous aquatic animals in southern Africa. A report of the Committee for Nature Conservation Research National Programme for Ecosystem Research. South African Scientific Programmes Report No. 144. Port Elizabeth, South Africa, 310pp.

de Silva, S.S., N.W. Abery \& T.T.T. Nguyen (2006). An evaluation of the role and impacts of alien finfish in Asian inland aquaculture. Aquaculture Research 37: 1-17.

FAO (2008-2009). Fisheries and Aquaculture topics. The State of World Fisheries and Aquaculture (SOFIA). Topics Fact Sheets. Text by Jean-Francois Pulvenis. Updated 2 April 2008. [Cited 2 December 2009]. http://www.fao.org/ fishery/sofia/en.

Gopi, K.C. (2000). Freshwater Fishes of Kerala state, pp 13-32. In: Ponniah, A.G. \& A. Gopalakrishnan (eds.). Endemic Fish Diversity of Western Ghats. NBFGR-NATP Publication 1. National Bureau of Fish Genetic Resources, Lucknow, India.

Gopi, K.C. \& C. Radhakrishnan (2002). Impact assessment of African Catfish (Clarias gariepinus) infestation on indigenous fish diversity in Manalur Grama Panchayat, Thrissur District, Kerala: a case study. ENVIS Newsletter, Zoological Survey of India 9(1-2): 9-12.

Kurup, B.M. \& C.T. Samuel (1985). Fish and fishery resources of Vembanad Lake, pp. 77-82. In: Ravindran, K., N.U. Nair, P.A. Perigreen, A.G.G. Pillai, P.A. Panicker \& M. Thomas (eds.). Harvest and Post- Harvest Technology of Fishes. Central Institute of Fisheries Technology (CIFT) \& Society of Fisheries Technologists (SOFTI), Kochi, India.

Kurup B.M., K.V. Radhakrishnan \& T.G. Manojkumar (2004). Biodiversity status of fishes inhabiting rivers of Kerala (S. India) with special reference to endemism, threats and conservation measures, pp. 163-182. In: Wellcome, R.L. \& T. Petr (eds.). Proceedings of LARS2. 2nd Large Rivers Symposium, Phnom Penh, Cambodia. 11th to 14th February 2003.

Lal, K.K., R.K. Singh, V. Mohindra, B. Singh \& A.G. Ponniah (2003). Genetic makeup of exotic catfish, Clarias gariepinus in India. Asian Fisheries Science 16: 229-234.

Middendorp, H.A.J (1998). African Catfish spread in Asia. Aquanews 13(3): 7-10.

Mishra, A., A.K. Pandey, A.K. Singh \& P. Das (2000). Genetic threats to ichthyodiversity including capture and culture stocks due to introduction of exotics and genetically modified fishes. Journal of Nature Conservation 12: 1-7.

Molur, S. \& S. Walker (1998). Conservation Assessment and Management Plan. Workshop Report by Zoo Outreach Organization, CBSG, Indian Edition, Coimbatore, 100pp.

Na-Nakorn, U. (1999). Genetic factors in fish production. A case study of the catfish, Clarias, pp. 175-187. In: Mustafa, S. (ed.). Genetics in Sustainable Fisheries Management. Fishing News Books, Malden MA.

Na-Nakorn, U., R. Vikrom \& J. Boon-Ngam (2004). llotriploidy increases sterility in the hybrid between Clarias macrocephalus and Clarias gariepinus. Aquaculture 237: 73-88.
Naylor, R., K. Hindar, I.A. Fleming, R. Goldburg, S. Williams, J. Volpe, F. Whoriskey, J. Eagle, D. Kelso \& M. Mangel (2005). Fugitive Salmon: assessing the risks of escaped fish from net pen aquaculture. Bioscience 55(5): 427-437.

Naylor, R., S.L. Williams \& D.R. Strong (2001). Aquaculture - a gateway for exotic species. Science 294: 1655-1656.

Pascal, G., van de Nieuwegiessen, J. Olwo, S. Khong, J.A.J. Verreth \& J.W. Schrama (2009). Effects of age and stocking density on the welfare of African catfish, Clarias gariepinus Burchell Aquaculture 288(1-2): 69-75.

Periyar Foundation (2006). Annual Report of Periyar Foundation 2005-2006. accessed from www. periyarfoundation.org/pdf/pf_annualreport05-06.pdf on September $18^{\text {th }} 2009$.

Raghavan, R. \& G. Prasad (2006). A needless diversification: a perspective on the unregulated introduction and culture of the Pacific White Shrimp Litopenaeus vannamei, in India. World Aquaculture 37(1): 8-12.

Raghavan, R., G. Prasad, A.P.H. Ali \& B. Pereira (2008). Exotic fish species in a global biodiversity hotspot: observations from River Chalakudy, part of Western Ghats, Kerala, India. Biological Invasions 10: 37-40.

Rahman, M.A., A. Bhadra, N. Begum, M.S. Islam \& M.F. Hussain (1995). Production of hybrid vigour cross breeding between Clarias batrachus Lin and Clarias gariepinus Bur. Aquaculture 138: 125-130.

Sadler, P., P. Pankhurst \& H. King (2001). High prevalence of skeletal deformity and reduced gill surface area in triploid Atlantic Salmon (Salmo salar L) Aquaculture 198: 369-386.

Singh, A.K \& W.S. Lakra (2006). Alien fish species in India: impact and emerging scenario. Journal of Ecophysiology and Occupational Health 6: 165-174.

Senanan, W., A.R. Kapuscinski, U. Na-Nakoran \& L.M. Miller (2004). Genetic impacts of hybrid catfish farming (Clarias macrocephalus X Clarias gariepinus) on native catfish farming in central Thailand. Aquaculture 235: 167184.

Sudhi, K.S. (2009). Threat of foreign invasion on rivers. The Hindu http://www.thehindu.com/2009/08/10/ stories/2009081053850400.htm accessed on 21st December 2009.

Sugunan, V.V. (2002). Clarias gariepinus (African catfish) gravitates into River Yamuna, Sutlej, Godavari: Angst comes true. Fishing Chimes 22: 50-52.

Thakur, N.K. (1998). A biological profile of the African Catfish Clarias gariepinus and impacts of its introduction in Asia, pp. 275-292. In: Ponniah, A.G., P. Das \& S.R. Verma (eds). Fish Genetics and Biodiversity Conservation. Natcon Publications, Muzzafarnagar (UP) India.

Welcomme, R.L. \& C. Vidthayanon (2003). The Impacts of Introduction and Stocking of Exotic Species in the Mekong Basin and Policies for their Control. MRC Technical Paper, Mekong River Commission, Cambodia, 65pp.

Winemiller, K.O. \& L.C. Kelso-Winemiller (1996). 
Comparative ecology of catfishes of the Upper Zambezi River floodplain. Journal of Fish Biology 49: 1043-1061.

WWF (2002). Information sheet on Ramsar Wetlands (RIS). Accessed online on March 182008 http://www.wetlands.org/reports/ris/2IN019en.pdf.

WWF (2006). Vembanad Kole Wetland. Accessed online on March 18 2008. http:// www.wwfindia.org/about_wwf/what_we_do/freshwater_wetlands/our_work/ ramsar_sites/vembanad_kol_wetland.cfm.

Yalcin, S., K. Solak \& I. Akyurt (2001). Certain reproductive characteristics of the Catfish (Clarias gariepinus Burchell, 1822) living in the River Asi, Turkey. Turkish Journal of Zoology 25: 453-460.
Author Details: K. KRISHNAKUMAR is a Programme Officer with the Community Environment Resource Center (CERC) of the Ashoka Trust for Research in Ecology and Environment (ATREE), Alleppey, Kerala, India. His interest is in understanding biological invasions in freshwater systems of Kerala. AnVAR Ali is a Senior Fellow at the Conservation Research Group, St. Albert's College, Kochi, Kerala, India interested in freshwater fish taxonomy. Benno Pereira is a Senior Fellow and Director of the Conservation Research Group, St. Albert's College, Kochi, India. His research interests are in biology and captive breeding of endemic freshwater fishes. RAJEEV RAGHAVAN is a Senior Fellow and Associate Director of the Conservation Research Group, St. Albert's College, Kochi, India. His interest is in conservation biology with special reference to freshwater fishes of Western Ghats.

Author Contributions: KK carried out the field surveys and sampling associated with the study; AA and BP carried out the biological analyses; RR and AA planned and designed the study, interpreted the results and wrote the manuscript. 